\title{
Droga, podróż, wędrówka w Tylko kochankowie przeżyją Jima Jarmuscha
}

\author{
Umarli podróżują szybko... \\ Bram Stoker, Dracula, 1897
}

\begin{abstract}
Two first decades of the $21^{\text {st }}$ century have revealed an increasing popularity of the horror genre. In particular, we have been witnessing the renaissance of Gothic cinema, especially the vampire sub-genre. It is conspicuous that the original vampire story formula has lately undergone numerous significant alterations. Vampires have evolved from cold and soulless monsters to humanised romantic heroes. In the new millennium, a static Gothic diegesis gets frequently replaced by a dynamic reality, in which movement is a predominant feature. This article is devoted to the motifs of the road, journey and travels in Jim Jarmusch' film Only Lovers Left Alive.
\end{abstract}

Keywords: horror, vampire, Gothic cinema, road, journey

Z dawać się może, że trudno o bardziej odległe gatunki filmowe niż horror gotycki i kino drogi. Paradygmaty klasycznego horroru wyznaczają wszakże wyraźnie strukturę, miejsce akcji i stylistykę diegetycznego świata ${ }^{1}$. Opuszczone stare zamki, owiane tajemnicą wnętrza i ponadnaturalni, ekscentryczni bohaterowie w sposób mało oczywisty wpisują się w estetykę nurtu, którego domeną jest

${ }^{1}$ Cechy klasycznego horroru szczegółowo omawia Noël Carroll w książe Filozofia horroru, wskazując na sztywne ustrukturyzwanie gatunku. Zob. N. Carroll, The Philosophy of Horror or Paradoxes of the Heart, Routledge, New York 1990. 
mobilność i rozwój techniczny². Niemniej jednak rzecz ma się inaczej w przypadku niezwykle popularnego dzisiaj kina wampirycznego. „Nieumarli” podróżują od samego początku historii kina. Już w pierwszej ocalałej luźnej adaptacji filmowej powieści Dracula, autorstwa irlandzkiego pisarza Brama Stokera ${ }^{3}$, przeniesionej na ekran przez klasyka niemieckiego ekspresjonizmu Friedricha Wilhelma Murnau’a w 1922 r., tytułowy bohater, Nosferatu (Max Schreck), udaje się w podróż z odległej Transylwanii do Niemiec ${ }^{4}$. Zabiera ze sobą trumnę wypełnioną ziemią z rodzimego kraju. Bagaż ten pozwala mu przetrwać na obczyźnie ${ }^{5}$.

Podobną podróż (lecz zgodnie z literackim pierwowzorem z Transylwanii do Anglii) odbywają bohaterowie kolejnych licznych adaptacji Draculi, między innymi w filmie Johna Badhama z 1979 r. czy Francisa Forda Coppoli z 1992. Nosferatu i Dracula dla swoich podróży wybierają drogę morską, podczas których nierzadko ofiarą padają członkowie załogi statku. Wraz z rozwojem gatunku wampiry podróżują coraz częściej, a podróż nie zawsze kończy się spustoszeniem okolicy i śmiercią ludzkich współpasażerów. Wampiryczni protagoniści Wywiadu z wampirem (1994) w reżyserii Neila Jordana ${ }^{6}$, podróżują do Europy w poszukiwaniu społeczności wampirów i lepszego „życia”. Przyczyną wędrówki rodziny Cullenów z Sagi Zmierzch (2008-2012) na podstawie serii powieści Stephenie Mayer jest konieczność ukrywania niezmieniającego się wieku wampirów i próba asymilacji z ludzką częścią społeczeństwa. Podróżują oni też dla przyjemności, z potrzeby poznania świata, co całkowicie odbiega od archetypu wampira ${ }^{7}$.

Koniec XX wieku i pierwsze dekady nowego milenium przyniosły radykalne zmiany w sposobie obrazowania bohatera wampirycznego. Dotychczasowy bo-

${ }^{2}$ Zob. D. Orgeron, Road Movies: From Muybridge and Méliès to Lynch and Kiarostami, Palgrave Macmillan, Londyn 2008.

${ }^{3}$ B. Stoker, Dracula, Penguin Random House, Londyn 2016. Powieść została wydana po raz pierwszy w 1897 r. nakładem wydawnictwa Archibald Constable and Company w Londynie. Nowe odkrycia wykazują, że pierwszą kinową wersją Draculi była zaginiona węgierska produkcja niema z 1921 r. pt. Śmierć Draculi (Drakula halála, reż. Károly Lajthay, Węgry 1921). Zob. M. Crișan, Dracula: An International Perspective, Palgrave Macmillan, Londyn 2017, s. 5.

${ }^{4}$ Nosferatu - symfonia grozy (Nosferatu, eine Symphonie des Grauens), reż. Friedrich Wilhelm Murnau, Niemcy: Film Arts Guild, 1922. Z powodu braku zgody wdowy Brama Stokera na ekranizację powieści, w swoim filmie Murnau zmienił miejsce akcji, nazwiska bohaterów oraz wiele innych szczegółów. Nie zapobiegło to jednak rozprawie sądowej i nakazowi zniszczenia wszystkich kopii. Szczęśliwie, jedna z kopii ocalała, a film szybko zyskał status arcydzieła kina. Zob. R.E. Guiley, The Encyclopedia of Vampires, Werewolves and Other Monsters, Checkmark Books, New York 2005, s. 215.

${ }^{5}$ Dracula w powieści Brama Stokera śpi w trumnie wypełnionej rodzimą ziemią, z której czerpie witalną siłę. Zob. B. Stoker, Dracula.

${ }^{6}$ Film jest adaptacją powieści amerykańskiej pisarki Anne Rice pod tym samym tytułem z $1976 \mathrm{r}$.

${ }^{7}$ Według tradycji i wyobrażeń ludowych wampir jest postacią pokrewną upiorom i jako taki pozbawiony jest potrzeb innych niż zaspokojenie instynktu. Zob. M. Janion, Wampir. Biografia symboliczna, słowo/obraz terytoria, Gdańsk 2002, ss. 144-155. 
hater, wiedziony instynktem, okrutny pozbawiony sumienia potwór, przerodził się w postać romantyczną, niegodzącą się z własną drapieżną naturą i stającą po stronie ludzkich wartości i ideałów. Taka ewolucja postaci wampira poskutkowała nieuniknionymi przemianami gatunku. Wampiryczne historie w dużej mierze zerwały z tradycją horroru.

Badacze David Bordwell i Kristin Thompson, w swoim słynnym akademickim opracowaniu zagadnień filmoznawstwa, stawiają następującą tezę: „o przynależności do gatunku horroru przede wszystkim decyduje oddziaływanie filmu na emocje widzów. Horror ma szokować, wstrząsać, wzbudzać obrzydzenie, czyli mówiąc krótko - przerażać”. Już w latach 90. antropolog Clifford Geertz zauważył jednak tendencję w rozwoju sztuki i nauki, którą określił mianem „mącenia gatunków”. W poświęconej temu zjawisku publikacji Geertz zauważa:

Zatarcie granic między gatunkami, to coś więcej niż przeobrażenie Harry’ego Houdiniego czy Richarda Nixona w postacie powieściowe. To coś więcej także niż opisywanie bandyckich hulanek na Środkowym Zachodzie na wzór romansu gotyckiego. To - rozważania filozoficzne przybierające formę krytyki literackiej [...], dywagacje naukowe prezentowane pod płaszczykiem beletrystycznych morceaux $[\ldots]^{9}$.

Teza Geertza tłumaczy potrzebę „mącenia” gatunkowego jako sposób na przetrwanie gatunków, które (jak w przypadku kina) po wielu latach powielania konwencji na ekranie stają przed groźbą petryfikacji i odejścia do lamusa. Według Geertza destabilizacja gatunków pociąga za sobą przełom interpretacyjny ${ }^{10}$. Stąd też ewolucja i unowocześnienie pierwotnej formy horroru są nie tylko zrozumiałe, ale i konieczne.

W przypadku nowych wampirycznych produkcji głównym celem nie jest już wywołanie strachu. Częściej stają się one powiastkami moralizatorskimi, mającymi na celu wzniecenie aksjologicznych refleksji u młodych widzów ${ }^{11}$. Louis de Pointe du Lac (Brad Pitt), bohater Wywiadu z wampirem, cierpi z poczucia braku sensu własnego nieumarłego „życia”. W powieści Anne Rice towarzysz Louisa, Lestat, podsumowuje tę postawę następującymi słowami: „W swoim romansie z ludzkim życiem stajesz się martwy dla natury wampira”"12. W Sadze Zmierzch

${ }^{8}$ D. Bordwell, K. Thompson, Sztuka filmowa: wprowadzenie, Wydawnictwo Wojciech Marzec, Warszawa 2014, s. 373.

${ }^{9}$ C. Geertz, O gatunkach zmq̨conych. Nowe konfiguracje myśli społecznej, „Teksty Drugie. Teoria literatury, krytyka, interpretacja” 2/1990, s. 113.

10 Ibidem.

${ }^{11}$ Problematyka moralności nowego modelu wampirów zostaje poddana analizie, między innymi, w książce Zmierzch i filozofia. Autorzy odnoszą się do wielu wymiarów egzystencjalnych udręk nieumarłych bohaterów serii powieści Stephenie Meyer. Zob. W. Irwin, R. Housel, J.J. Wisnewski, Zmierzch i filozofia. Wampiry, wegetarianie i pogoń za nieśmiertelnościq, Prószyński i S-ka, Warszawa 2009.

12 A. Rice, Interview with the Vampire, Futura Books, Londyn 2004, s. 90 (tłum. własne). Problem wewnętrznego rozdarcia bohatera Wywiadu z wampirem omówiony został także w książce 
Edward Cullen (Robert Pattinson) z pobudek moralnych odmawia picia ludzkiej krwi. Mimo to utwierdzony jest w przekonaniu, że z powodu braku duszy, którą, jak wierzy, utracił w momencie przemiany w wampira, jest potworem skazanym na wieczne potępienie. W dodatku, jak zauważa Bendan Shea, „martwi się, że już stracił duszę, a po przemianie [ukochanej - M.G.] Belli w wampira pozbawi ją jej własnej”. Oznajmia więc: „Nie mogę bez ciebie żyć, ale nie unicestwię twojej duszy"13. W filmie Dracula: Historia nieznana (2014) Gary’ego Shore’a książę Vlad Tepes (Luke Evans) przyjmuje klątwę wampira, a następnie poświęca „życie” by ratować syna. Współczesne wampiry odzwierciedlają więc ludzkie wartości moralne, a uczłowieczenie wampirycznych bohaterów w trzecim milenium skazuje ich na przeżywanie dramatów wewnętrznego rozdarcia i ludzkich dylematów. Tradycyjny wzorzec okrutnego wampira krwiopijcy przeistoczył się w romantycznego kochanka, ojca rodziny, społecznika. W rezultacie filmy wampiryczne doczekały się interpretacji w kontekście społecznym, filozoficznym i etycznym odmiennych niż te z pierwszej połowy XX wieku. Dzisiejszy bohater wampiryczny odzwierciedla pełnię ludzkich pragnień i dążeń, także społecznie akceptowanych, a nie jak dawniej ukrytą ciemną część natury człowieka lub zagrożenie nadchodzące z zewnątrz ${ }^{14}$.

Zmienia się też miejsce akcji neogotyckich filmów poświęconych wampirycznej tematyce. $Z$ archetypicznych ruin starych zamczysk współczesne wampiry wędrują do dużych miast, gdzie łatwiej skryć się w anonimowej miejskiej „dżungli”.

W 2013 r. na ekrany kin wszedł film Jima Jarmuscha Tylko kochankowie przeżyjq, w którym amerykański reżyser prezentuje epizod z „życia” małżeństwa kilkusetletnich wampirów o imionach Adam (Tom Hiddleston) i Ewa (w filmie Eve, Tilda Swinton). Film skierowany do nieco starszej publiczności, szybko zdobył status obrazu kultowego. Przyczyną stał się zapewne przesączony nostalgią i pełen filozoficznej refleksji klimat, którym, znany z zamiłowania do sztuki i kultury, Jarmusch wypełnił swój diegetyczny świat. Oczywisty jest też magnetyczny urok nietuzinkowej pary głównych bohaterów.

Jarmusch osadza akcję we współczesnym Detroit w stanie Michigan, gdzie w podmiejskim industrialnym gąszczu egzystuje Adam. Zamieszkuje on opuszczony dom, w którym gromadzi muzyczne sprzęty i komponuje mroczną, popularną w undergroundowych klubach muzykę. Z wyboru większość czasu spędza w domu, gdzie zmaga się z depresją wywołaną, jak sam twierdzi, „zombizmem”

Anny Gemry pt. Od gotycyzmu do horroru. Wilkołak, wampir i monstrum Frankensteina w wybranych utworach, Wydawnictwo Uniwersytetu Wrocławskiego, Wrocław 2008, ss. 228-237.

${ }^{13}$ B. Shea, Ugryźć czy nie ugryźć: Zmierzch, nieśmiertelność i znaczenie życia w: Zmierzch i filozofia..., s. 96.

${ }^{14}$ Magdalena Kamińska omawia zjawisko powstania „emocjonalnego wampira” w swojej monografii Upiór w kamerze. Zarys Kulturowej historii kina grozy, Arsenał, Poznań 2016, ss. 174-175. Tendencję łączenia gatunkowych cech klasycznego horroru z rozważaniami natury etyczno-moralnej badaczka określa mianem „popfilozoficznego sosu”, w którym utopione zostały kolejne produkcje wampiryczne końca XX wieku. 
współczesnych ludzi. „To ci wszyscy zombie i jak traktują świat. Czuję się, jakby cały piasek przesypał się w klepsydrze"15 - wyznaje w telefonicznej rozmowie z żoną. Ewa rusza z pomocą mężowi, organizując nocną podróż ze swojego miejsca zamieszkania Tangeru do Detroit. W dalszej części filmu obserwujemy parę spędzającą wspólnie czas w Detroit i stawiającą czoła problemom, które przysparza im odwiedzająca małżonków młodsza siostra Ewy, Ava (Mia Wasikowska).

Paradoksalnie, pomimo statycznych, ciemnych neogotyckich scenerii nocnych miast i wnętrz, w których rozgrywa się historia Adama i Ewy, film ukazuje małżonków w drodze. Zawiązanie akcji przedstawia Ewę w podróży na inny kontynent. Nieumarła bohaterka planuje podróż wbrew własnym upodobaniom i na przekór piętrzącym się trudnościom - musi unikać dziennego światła i zaopatrzyć się w pożywienie (krew). Podobną podróż w przeciwnym kierunku odbywają małżonkowie pod koniec filmu, kiedy to z powodu występków Avy muszą uciekać z Detroit w poszukiwaniu bezpiecznego azylu.

Jarmusch oferuje widzom także obraz idyllicznej podróży kochanków przez przedmieścia Detroit, gdzie przez długie lata nieobecna w zachodnim świecie Ewa przypatruje się zmianom i naturze współczesnego amerykańskiego miasta. Sekwencja jazdy samochodem odpowiada stylistyce klasycznego kina drogi ${ }^{16}$ odnosi się do tradycji wędrowania i próby poszukiwania „amerykańskiego snu”. Para odwiedza historyczne miejsca, odarte przez „zombie” z pierwotnych wartości, zapomniane lub przemienione w opustoszałe industrialne hale. Nocne, wyludnione miasto staje się metaforą kulturowego wyjałowienia, zobojętnienia i alienacji społeczeństwa trzeciego milenium. Samotność kochanków wędrujących przez krajobrazy postindustrialnej nocnej metropolii odzwierciedla przepastną pustkę materialistycznej egzystencji współczesnego człowieka.

Wizja ta uwydatnia się szczególnie w odniesieniu do przywoływanych w filmie dzieł sztuki i osiągnięć myśli i techniki. Jak sugeruje scenariusz, nie jest do końca pewne, które z wielkich dzieł zostały stworzone przez ludzi. Taką kulturową podróż rozpoczyna Jarmusch już w pierwszych sekwencjach filmu, kiedy to w Tangerze Ewa spotyka się z zaprzyjaźnionym wampirem i mentorem, Christopherem Marlowe’em (John Hurt). Rozmowy dwojga przyjaciół odnoszą się do znanych z historii spekulacji na temat autorstwa dzieł Williama Shakespeare' ${ }^{17}$, do którego ostatecznie przyznaje się Marlowe. Hołd wielkim kultury i nauki oddany zostaje bez słów w scenach poprzedzających emigrację Adama i Ewy. W XXI wieku wampirzyca nie potrzebuje już ziemi i trumny, bez których nie mógł obejść się Dracula. Jedynym

15 Tylko kochankowie przeżyją, reż. Jim Jarmusch, Wielka Brytania, Niemcy: Recorded Picture Company, Pandora Film, 2013 (tłum. własne).

${ }^{16}$ Zob. D. Orgeron, Road Movies...

17 Istnieją teorie dowodzące, że wpółczesny Shakespeare’owi dramaturg Christopher Marlowe był autorem dzieł Shakespeare’a. Zob. S.L. Blumenfeld, The Marlowe-Shakespeare Connection: A New Study of the Authorship Question, McFarland \& Co Inc., Jefferson 2008. 
bagażem, jaki Ewa zabiera ze sobą do Detroit, jest walizka z książkami. Widzowie towarzyszą bohaterce w metafizycznej podróży podczas rytuału pakowania. Scena ukazuje niemal zmysłową przyjemność Ewy w obcowaniu z ulubionymi dziełami. Wyraźne staje się to, że właśnie te dzieła stanowią duchową strawę, która pozwala kochankom przetrwać stulecia egzystencji ogołoconej z wartości. Wśród wybranych przez Ewę pozycji znajdują się tomy w różnych językach i z odmiennych kręgów kulturowych: Samuel Beckett, Miguel de Cervantez, Yukio Mishima, Franz Kafka i wiele innych.

Fascynacje Adama w dużej mierze odnoszą się do nauki. Jasne jest, że małżonkowie prowadzą rozmowy o sztuce, technice i ich walorach od stuleci, lecz w trzecim milenium Adam traci wiarę w wyznawane ideały. Ogarnięty egzystencjalnym smutkiem wyznaje: „Nie mam bohaterów. [...] Naukowcy? Popatrz, co z nimi zrobili. Pitagoras - zamordowany. Galileo - uwięziony. Kopernik - wyśmiany. Stary, dobry Newton, owiany tajemnicą i zepchnięty w czeluści alchemii. Tesla - zniszczony. Jego cudowne możliwości zignorowane. I wciąż przeklinają Darwina - wciąż! Tyle, jeśli chodzi o naukowców”18.

Niemniej jednak galeria na ścianie Adama wskazuje na odmienny stan rzeczy. Oprawione w ramy fotografie ukazują podobizny wielkich tego świata. Wśród nich rozpoznajemy twarze muzyków, między innymi: Johanna Sebastiana Bacha, Franza Schuberta, Gustava Mahlera, Billie Holiday, Hanka Williamsa, Johna Coltrane’a, Toma Waitsa; literatów: Williama Blake’a, Christophera Marlowe’a, Lorda Byrona, Percy'ego Bysshe Shelley’ego, Mary Wollstonecraft, Johna Keatsa, Jane Austen, Edgara Allana Poe, Emily Dickinson, Charles’a Baudelaire’a, Oscara Wilde’a, Franza Kafki, Marka Twaina, Samuela Becketta; naukowców: Isaaca Newtona, Nikoli Tesli; artystów: Bustera Keatona, Harpo Marxa i wielu innych bohaterów nauki i kultury.

Dramatyczną transformację wampirycznych postaci, charakterologiczne oderwanie od gotyckich wzorów i ich ograniczeń wskazuje Jarmusch metaforycznie dotychczasowa konieczność spoczynku w ziemi z rodzimego kraju zastąpiona zostaje koniecznością chłonięcia sztuki. W rezultacie wampiry Jarmuscha stają się wolne. Miejsce „urodzenia” (przeistoczenia w wampira) już ich nie definiuje. Mogą wędrować i samodzielnie wybierać miejsce zamieszkania. Wolni są też w wyborze stylu nieumarłego życia, jak również w tym, w jakim stopniu będą uczestniczyć w tworzeniu współczesnego świata.

Tylko kochankowie przeżyjq̨ staje się więc manifestem dynamicznej ewolucji gatunku - kolejnym ${ }^{19}$ dowodem na to, że kino wampiryczne wyrwało się z gatunkowych sztamp horrorów klasy B. Nieumarli protagoniści Jarmuscha dalecy są od jednowymiarowości krwiożerczych potworów z minionych epok. Wampir nowego

${ }_{18}$ Tylko kochankowie przeżyja (tłum. własne).

19 Obok kilku wcześniejszych znaczących adaptacji Draculi w reżyserii: Philipa Saville’a (1977), Wernera Herzoga (1979) czy Francisa Forda Coppoli (1992). 
milenium stał się wysublimowanym koneserem sztuki, oczytanym, elokwentnym artystą tworzącym własny wkład do świata kultury i techniki. Adam, Ewa i Marlowe, razem z wyznawaną filozofią, wartościami i interpretacją świata, jawią się jako postacie bardziej ludzkie niż pojawiający się w filmie ludzie. Nieczuli na problemy otaczającej rzeczywistości „zombie”, sprawiają wrażenie zawieszonych nieruchomo w czasie i miejskiej przestrzeni. Kontrastem dla egzystencjalnego bezruchu jest nocny świat wampirów, który, choć ograniczony koniecznością unikania dziennego światła, jest dynamiczny i pełen twórczych możliwości. Naścienne wizerunki bohaterów Adama służą nie tylko wspomnieniu ich wiekopomnych dokonań. Stają się drogowskazami i nawołaniem do kreatywnych działań, wyznaczają kierunek dalszej wędrówki i przypominają, że podróż musi trwać.

Transformacja wampirycznego bohatera w trzecim tysiącleciu przyniosła więcej zmian niż iście ludzką fascynację kulturą i niechęć do stagnacji. Wampiry odkryły też sposób żywienia, wykluczający okrucieństwo względem człowieka. „To takie średniowieczne!”20 , komentuje Ewa. Różne są metody rozwiązania problemu cywilizowanego zdobywania pożywienia: Cullenowie z Sagi Zmierzch przechodzą na „wegetarianizm” i zadawalają się krwią zwierzęcą, Jarmuschowskie wampiry natomiast zawierają układy z lekarzami i pracownikami banków krwi. Zmiana ta, wiedziona pobudkami etycznymi, jest kolejnym dowodem uczłowieczenia wampira.

Jarmusch podkreśla kontrast między tradycją a współczesnością poprzez wprowadzenie archetypicznej postaci Avy. Młodsza siostra Ewy wnosi chaos do poukładanego świata małżonków. Pogardza wartościami i z dezaprobatą odnosi się do ascetycznego i odludnego stylu życia Adama. Brak poszanowania dla nowych i nudnych (w opinii Avy) zwyczajów siostry i szwagra powoduje kryzys, w rezultacie którego Adam i Ewa muszą w pośpiechu opuścić Detroit. Wizyta w nocnym klubie i późniejsze zniknięcie ludzkiego przyjaciela Adama, Iana (Anton Yelchin), który pada ofiarą głodu Avy, stawia małżonków w pozycji uciekinierów wyjętych spod prawa. Niezamierzona podróż z Detroit do Tangeru staje się wędrówką wygnańców, z której kochankowie nie wychodzą bez szwanku.

W Tangerze wygłodniałe małżeństwo kieruje się do drzwi Marlowe’a z nadzieją na pomoc w zdobyciu pożywienia. Zastają go jednak w agonii po wypiciu zatrutej krwi. Przybywają w porę, aby go pożegnać. Utrata Marlowe’a skazuje wycieńczonych po długiej podróży kochanków na głód. Sprawdza się apokaliptyczna wizja Adama wygłoszona w Detroit: „Teraz zdołali nawet zatruć własną krew, nie wspominając o wodzie”21. Jarmusch porusza dotkliwy we współczesnym świecie problem zagrożeń ekologicznych wynikających z krótkowzrocznych działań człowieka. Ostatnie sceny filmu ukazują bohaterów błąkających się po uliczkach Tangeru. Scena odpowiada estetyce wcześniej omawianej wędrówki

${ }^{20}$ Tylko kochankowie przeżyjq (tłum. własne).

${ }^{21}$ Ibidem. 
przez Detroit. Dekadencki nastrój potęgowany jest przez wizje wąskich, ciemnych uliczek, oświetlonych księżycowym światłem zaułków i obrazy wycieńczonych, pozbawionych nadziei wampirów. Chwilowe ukojenie przynosi im dobiegająca z nocnej kawiarni muzyka. Kochankowie zatrzymują się, żeby choć przez chwilę dać się ponieść kojącym dźwiękom. Kolejna sekwencja ukazuje Adama i Ewę przypatrujących się parze zakochanych siedzących na pobliskiej ławce. Jasne staje się, że nie ma innego wyjścia - Adam i Ewa będą musieli powrócić do starych „średniowiecznych” metod żywienia.

Jarmusch buduje swój filmowy świat na zasadzie kontrastów: martwi „zombie” - nieumarłe wampiry; sztuka i kultura - prostota i brak wykształcenia; postęp cywilizacji - ciemnota i zacofanie; moralność i etyka - upadek zasad i degradacja wartości. Ciekawy jest także tytuł filmu, który nawiązuje do wielokrotnie przywoływanego w filmie motywu wampirów-kochanków, jedynych prawdziwie żywych i bardziej ludzkich od ludzi. Przytaczany wcześniej filozoficzny wywód Adama obarcza ludzkich „zombie” winą za opłakany stan współczesnego świata - zatracenie wartości i zaprzepaszczenie wszelkich ludzkich talentów i możliwości. Działania „zombie” ostatecznie skazują wampirycznych bohaterów na powrót do barbarzyńskiego stylu „życia”, od którego udało im się uciec przed wiekami. Tytuł filmu nawiązuje do powieści science fiction autorstwa Dave’a Wallisa z 1964 r., w której po śmierci wszystkich dorosłych, nastolatkowie muszą zbudować nowy porządek świata ${ }^{22}$. Treść filmu Jarmuscha nie powiela problemu powieści bezpośrednio, jednakże oczywiste jest, że Jarmuschowscy bohaterowie znajdują się w analogicznej sytuacji, w której zmuszeni są budować nowe uniwersum, bo stare zasady nie znajdują racji bytu. Jedyną szansą na przetrwanie stają się uczucia, poszanowanie moralności i dbałość o otaczający ich świat. Film Jarmuscha można traktować więc jako metaforę i apokaliptyczną przestrogę dla globalnego społeczeństwa trzeciego milenium.

Adam, Ewa i Marlowe, jak również wiele innych postaci w kinie grozy XXI wieku, niemal całkowicie zrywają z wampiryczną tradycją. Inne stają się też zasady tworzenia diegezy. Kino wampiryczne przestaje być kinem męskim. Nowe obrazy coraz częściej stawiają w centrum wampirzyce, które nie pełnią już tylko roli pięknego dodatku (jak w przypadku wielu wersji Draculi powstałych w pierwszej połowie XX wieku). Wampirzyce współczesnego kina są pełnoprawnymi bohaterkami, które w równej mierze przyczyniają się do kształtowania świata. Wyraźnie widać to w Tylko kochankowie przeżyją. Mimo wielkiego oddania mężowi, Ewa jest niezależną kobietą - wykształconą, broniącą własnych przekonań. Z wyboru mieszka sama w wybranym przez siebie miejscu i umie zadbać o swoje potrzeby. W filmie wielokrotnie widzimy ją w roli silnej i dynamicznej kobiety, która w chwili kryzysu Adama podejmuje wszelkie decyzje i staje się głosem rozsądku, ostoją

${ }^{22}$ Zob. D. Wallis, Only Lovers Left Alive, Valancourt Books, Richmond, VA 2015. Po raz pierwszy książka została wydana w 1964 r. nakładem brytyjskiego wydawnictwa Anthony Blond. 
i opiekunką w jednym. Ostatnia scena wędrówki przez Tanger w poszukiwaniu rozwiązania dramatycznej sytuacji ukazuje Ewę jako postać o wiele silniejszą od Adama. To ona podtrzymuje go fizycznie i psychicznie, jest motorem ich wspólnego działania i ciągłego ruchu. Instynktownie wie, że aby przetrwać, nie mogą zatrzymać się w drodze.

Taka interpretacja zgodna jest z symboliką imion bohaterów Jarmuscha. W biblijnej opowieści to właśnie Ewa jest przyczyną pierwszej wędrówki człowieka - wysyła ona w drogę cały gatunek ludzki. Działania Ewy zapoczątkowały wędrowanie w poszukiwaniu lepszego świata, a motyw wędrówki stał się nieodzowną częścią kultury. Na stałe zagościł także w kinie. Według Brama Stokera „umarli podróżują szybko”23, jednakże dla nieumarłych wampirów nowego tysiąclecia podróż jest procesem znacznie bardziej złożonym. Film Tylko kochankowie przeżyja przedstawia motyw podróży na wielu płaszczyznach: poprzez fizyczne podróże przez miasta, realizację etosu amerykańskiego snu, czyli poszukiwanie lepszego życia i kształtowanie własnej tożsamości. Gruntowna transformacja bohatera stanowi wszak meritum nurtu kina drogi ${ }^{24}$. Film ukazuje też podróż w obrębie gatunku - ewolucję od prymitywnego horroru klasy B i jednowymiarowego protagonisty-potwora z początków medium kinowego, do artystycznego obrazu nowego milenium, w którym nieumarli bohaterowie budzą empatię widzów i wzbudzają refleksje na temat istoty człowieczeństwa i natury współczesnego świata.

\section{Literatura}

Blumenfeld S.L., The Marlowe-Shakespeare Connection: A New Study of the Authorship Question, McFarland \& Co Inc., Jefferson 2008.

Bordwell D., Thompson K., Sztuka filmowa: wprowadzenie, Wydawnictwo Wojciech Marzec, Warszawa 2014.

Carroll N., The Philosophy of Horror or Paradoxes of the Heart, Routledge, New York 1990. Crișan M.-M., Dracula: An International Perspective. Palgrave Macmillan, Londyn 2017. Geertz C., O gatunkach zmq̨conych. Nowe konfiguracje myśli społecznej, „Teksty Drugie. Teoria literatury, krytyka, interpretacja” 2/1990, Instytut Badań Literackich PAN i Stowarzyszenie Pro Cultura Litteraria, Warszawa 1990.

Gemra A., Od gotycyzmu do horroru. Wilkołak, wampir i monstrum Frankensteina w wybranych utworach, Wydawnictwo Uniwersytetu Wrocławskiego, Wrocław 2008.

Guiley R.E., The Encyclopedia of Vampires, Werewolves and Other Monsters, Checkmark Books, New York 2005.

Irwin W., Housel R., Wisnewski J. J., Zmierzch i filozofia. Wampiry, wegetarianie i pogoń za nieśmiertelnościq, Prószyński i S-ka, Warszawa 2009.

Janion M., Wampir. Biografia symboliczna, słowo/obraz terytoria, Gdańsk 2002.

${ }^{23}$ B. Stoker, Dracula, s. 11 (tłum. własne).

${ }^{24}$ Zob. W. Salles, Notes for a Theory of the Road Movie, „The New York Times Magazine” November 11, 2007. 
Kamińska M.. Upiór w kamerze. Zarys Kulturowej historii kina grozy, Arsenał, Poznań 2016. Orgeron D., Road Movies: From Muybridge and Méliès to Lynch and Kiarostami, Palgrave Macmillan, Londyn 2008.

Rice A., Interview with the Vampire, Alfred A. Knopf, New York 1976; Futura Books, Londyn 2004.

Salles W., Notes for a Theory of the Road Movie, „The New York Times Magazine” November 11, 2007.

Stoker B., Dracula, Archibald Constable and Company, Londyn 1897; Penguin Random House, Londyn 2016.

Wallis D., Only Lovers Left Alive, Anthony Blond, Londyn 1964; Valancourt Books, Richmond, VA 2015.

\section{Filmografia}

Dracula (Bram Stoker's Dracula), reż. Francis Ford Coppola, Columbia Pictures, USA 1992. Dracula, reż. John Badham, Universal Pictures, Wielka Brytania - USA 1979.

Dracula: Historia nieznana (Dracula Untold), reż. Gary Shore, Legendary Pictures, USA 2014.

Hrabia Dracula (Count Dracula), reż. Philip Saville, Wielka Brytania: BBC, 1977.

Nosferatu - symfonia grozy (Nosferatu, eine Symphonie des Grauens), reż. Friedrich Wilhelm Murnau, Film Arts Guild, Niemcy 1922.

Nosferatu wampir (Nosferatu: Phantom der Nacht), reż, Werner Herzog, Niemcy: Werner Herzog Filmproduktion, Gaumont, Zweites Deutsches Fernsehen, 1979.

Saga Zmierzch: Księżyc w nowiu (The Twilight Saga: New Moon), reż. Chris Weitz, Summit Entertainment, USA 2009.

Saga Zmierzch: Przed świtem. Część 1 (The Twilight Saga: Breaking Dawn - part 1), reż. Bill Condon, Summit Entertainment, USA 2011.

Saga Zmierzch: Przed świtem. Część 2 (The Twilight Saga: Breaking Dawn - part 2), reż. Bill Condon, Summit Entertainment, USA 2012.

Saga Zmierzch: Zaćmienie (The Twilight Saga: Eclipse), reż. David Slade, Summit Entertainment, USA 2010.

Saga Zmierzch: Zmierzch (Twilight), reż. Catherine Hardwicke, Summit Entertainment, USA 2008.

Śmierć Draculi (Drakula halála), reż. Károly Lajthay, Węgry 1921 (Zaginiony).

Tylko kochankowie przeżyjq (Only Lovers Left Alive), reż. Jim Jarmusch, Wielka Brytania, Recorded Picture Company, Pandora Film, Niemcy 2013.

Wywiad z wampirem (Interview with the Vampire: The Vampire Chronicles), reż. Neil Jordan, Warner Bros., USA 1994. 